\title{
Trauma of the Male Genitals in the Teaching Hospital Sylvanus Olympio of Lome: Lesional and Therapeutic Aspects
}

\author{
Kodjo Tengue ${ }^{1}$, Edoé Viyomé Sewa ${ }^{1}$, Komi Hola Sikpa ${ }^{2}$, Gnimdou Botcho ${ }^{2}$, Essodina Padja ${ }^{1}$, \\ Matchonna Tchilabalo Kpatcha' ${ }^{2}$, Ekoué David Dosseh ${ }^{3}$
}

${ }^{1}$ Department of Urology, University Teaching Hospital of Lomé, Lomé, Togo

${ }^{2}$ Department of Urology, University Teaching Hospital of Kara, Kara, Togo

${ }^{3}$ Department of Surgery, University Teaching Hospital of Lomé, Lomé, Togo

Email: *viyomedoe35@yahoo.fr, *viyomedoe@gmail.com

How to cite this paper: Tengue, K., Sewa, E.V., Sikpa, K.H., Botcho, G., Padja, E., Kpatcha, M.T. and Dosseh, E.D. (2021) Trauma of the Male Genitals in the Teaching Hospital Sylvanus Olympio of Lome: Lesional and Therapeutic Aspects. Open Journal of Urology, 11, 31-35.

https://doi.org/10.4236/oju.2021.112004

Received: December 18, 2020

Accepted: February 4, 2021

Published: February 7, 2021

Copyright () 2021 by author(s) and Scientific Research Publishing Inc. This work is licensed under the Creative Commons Attribution International License (CC BY 4.0).

http://creativecommons.org/licenses/by/4.0/

\begin{abstract}
Introduction: Trauma of the external male genital organs (TEMGO) is multifaceted and rare. The objective of this work was to provide an overview of these lesions by describing the epidemiology, the diagnostic approach, their therapeutic and prognostic aspects. Materials and Methods: It was a retrospective study carried out over a ten-year period, from January 1, 2009 to December 31, 2018. It included male patients, admitted and treated in surgical emergencies and in the urology department of the Sylvanus Olympio Teaching Hospital in Lomé for trauma of male external genital organs. Results: Thirty-five cases had been collected. They had represented $1.5 \%$ of urological emergencies. The subjects were young with a mean age of $29.6 \pm$ 3.1 years, with extremes of 18 and 60 years. Trauma to the penis was more frequent and found in $60 \%$ of cases, with the mechanism of coitus misstep in $54.3 \%$, leading to a fracture of the penis. Testicular contusions were found in $22.9 \%$ of the cases. The ultrasound was performed in 6 patients. Four orchidectomies were performed for an unsustainable testicle found at scrototomy. The postoperative had been simple in all cases. Fifteen patients (42.8\%) had been regularly followed on 18 months. Residual testicular pain and moderate erectile dysfunction was noted respectively in 3 and 2 patients. Conclusion: TEMGO, although rare, require perfect knowledge for adequate therapeutic decisions, as they can compromise the functional prognosis of concerned organs.
\end{abstract}

\section{Keywords}

Genital Organs, Trauma, Scrototomy, Togo 


\section{Introduction}

Trauma of the male genitals includes various penis and bursa lesions, which occurred during an assault [1]. They can affect the functional and vital prognosis of the organs affected. These traumas are poorly described in the literature in developing countries though they are potentially serious and can come within the scope of polytrauma [2] [3]. In the study of Diabaté et al. [4], they represented $3.36 \%$ of all urological emergencies. Their rarety is confirmed by Coulibaly et al. [5] who had a frequency of 2 cases by year in their study about bursae trauma. In order to provide an overview of these lesions, we undertook this work aiming at describing the epidemiology, the diagnostic approach as well as their therapeutic and prognostic aspects in our practice.

\section{Materials and Methods}

This work was carried out at the Teaching Hospital Sylvanus Olympio of Lomé (TOGO). It was a retrospective study over a ten-year period, from January 1 , 2009 to December 31, 2018. It included male patients admitted in the emergency unit of this hospital for trauma of the genitals. We did not include in this study patients admitted for urinary tract trauma. Patient files had been used to collect the data which were registered on a survey form. The parameters studied were: age, circumstances of the trauma, lesional diagnosis, paraclinical assessment, treatment and short and long-run follow-up. The data, had been processed with Epi info Version 6.0 computer software. The quantitative variables are expressed as means with standart deviation, and qualitative variables in the form of tables.

\section{Results}

During the study period, 35 cases of trauma of the male genitals were registered. They represented $1.5 \%$ of the urological emergencies. The average age of the patients was $29.6 \pm 3.1$ years, with extremes of 18 and 60 years. There were 21 cases of penis trauma and 14 cases of bursa trauma. Coitus misstep was the most common mechanism of occurrence, in $54.2 \%$ of cases, as shown in Table 1 .

Among the patients who had a road accident, 4 cases of polytrauma with cranioencephalic trauma and abdominal contusion were registered. The diagnosis of genitals trauma was clinical in all cases: pain was found in all patients and a vaginal hematocele in 9 cases. Nevertheless, an ultrasound was carried out with 6 patients: these were two cases of a penis fracture, and 4 cases of trauma of the bursa with vaginal hematocele. The lesion assessment of these traumas is recorded in Table 2.

Therapeutically, $94.3 \%$ of the patients had undergone surgery and two patients had received medical treatment. This treatment consisted of the administration of analgesics, anti-inflammatories and antibiotics. It involved 1 case of spermatic cord hematoma and 1 case of testicular contusion. The surgical procedures are listed in Table 3.

The operative suites had been simple in all cases. On an average follow-up of 
Table 1. Distribution of patients by mechanism.

\begin{tabular}{ccc}
\hline & $\mathbf{n}$ & $\%$ \\
\hline Coitus misstep & 19 & 54.2 \\
Road Accident & 14 & 40 \\
Physical Assault & 1 & 2.9 \\
Self-harm & 1 & 2.9 \\
Total & 35 & 100 \\
\hline
\end{tabular}

Table 2. Report of lesions in genital trauma.

\begin{tabular}{ccc}
\hline & n & \% \\
\hline Penile fracture & 19 & 54.3 \\
Testicular contusion/intra testicular hematoma + hematocele & 8 & 22.9 \\
Scrotum injury & 3 & 8.6 \\
Partial penile amputation & 2 & 5.7 \\
Spermatic cord hematoma & 2 & 5.7 \\
Testicular fracture + hematocele & 1 & 2.8 \\
Total & 35 & 100 \\
\hline
\end{tabular}

Table 3. Surgical procedures.

\begin{tabular}{ccc}
\hline & $\mathbf{n}$ & $\%$ \\
\hline Repair of cavernous body albuginea & 19 & 57.6 \\
Hematocele drainage and hemostasis & 5 & 15.2 \\
Orchiectomy & 4 & 12.1 \\
Scrotum injury repair & 3 & 9 \\
Regularization of amputation stump & 2 & 6.1 \\
Total & 33 & 100
\end{tabular}

18 months, 15 patients (42.8\%) had been regularly followed. We had noted residual testicular pain with 3 patients along with bursa trauma. Moderate erectile dysfunction had been noted with 2 patients carrying broken cavernous body.

\section{Discussion}

Trauma to the genitals is relatively rare and very often described in publications concerning urogenital trauma in general; they had been indeed $10.5 \%$ and $12.9 \%$ in the respective works of Dekou et al. [2] and Kambou et al. [1]. In this study, they were $1.5 \%$ of urological emergencies, below the rate found by Diabate et al. [4] in Senegal, which had recovered 3.36\%. This difference would result from the inclusion of urinary trauma in their work; our study had only taken into account trauma of the genitals. The potential seriousness of these lesions lies in their possible impact on the sexuality and fertility of patients, since the subjects af- 
fected are most often young. Our average age of 29.6 years agrees with that of several authors as regards trauma [5] [6]. Indeed, young people are very active subjects and more exposed to all kinds of trauma, particularly those resulting from road accidents. The latter mechanism is quite common because there is a particularity for lesions of the penis; they are more vulnerable during an erection. According to Simonin et al. [6], there is a human defense instinct for the external genitalia, which protects the penis from trauma. Nevertheless, during erection, the rigid penis is more exposed and the albuginea of cavernous body thins and becomes more fragile. In our work, trauma to the penis was often caused by a coitus misstep. Sow et al. [7] also found this.

A meticulous clinical examination usually enables to make the diagnosis in trauma of the penis. The lesions during an amputation are diagnosed at the inspection whereas the rupture of the cavernous body requires a series of questions specifying the very evocative mechanism and a meticulous physical examination before its diagnosis. In fact, the "Rollin sign" of the fracture focus enable the diagnosis to be made [6]. However, in some cases of doubt, it may be necessary to carry out additional examinations including ultrasound, which allows to find the defect on the albuginea [3]. Our two cases were about patients with significant edema of the penis with questioning that was not very suggestive. However, even though this examination is accessible and easily achievable it can be defective. Thus, for Turpin et al. [8], MRI is the examination of choice in the exploration of lesions; it has a medico-legal value in this pathology whose subsequent complications can impair erectile function. In our context, MRI is a very expensive examination and therefore inaccessible for most the patients.

Although we do not need ultrasound in trauma of the penis, it is required in the case of bursa trauma. Indeed, for Lardellier et al. [9], ultrasound remains the reference examination, especially when it is coupled with Doppler. Though the place of this examination remains controversial for the fact that its results are "operator dependent" [5] [10]; it was carried out in our work in 4 patients who had bursa trauma. However, its realization should not delay treatment, especially since the hematocele, witness to a hemorrhage, should lead to the decision to explore by scrototomy.

Therapeutically, the treatment of broken cavernous body was surgical in all our patients, by albugineorraphy as recommended by Grima et al. [11]. There is no longer place for drug therapy nowadays [7]. The problem with the amputations of penis is essentially the viability of the amputated stump. In our work a regularization of the stump with creation of a neo-meatus had been carried out. According to Diabaté et al. [12], reimplantation should be attempted as far as possible to maintain the body pattern and enable sexual activity. As far as bursa trauma is concerned, the treatment depended on the lesions observed during the scrototomy. Evacuation of the hematocele enables a complete lesion assessment. That is how 4 orchidectomies were performed for testicular fractures and intratesticular hematomas with necrosis of the pulp. 


\section{Conclusion}

Genital trauma is rare in our practice but requires a good knowledge. Their evolution can lead to loss of testicle and erectile dysfunction. The management is most often surgical.

\section{Conflicts of Interest}

The authors declare no conflicts of interest regarding the publication of this paper.

\section{References}

[1] Kambou, T., Ouattara, A., Zare, C., Ouattara, A.M., Pare, A.K. and Sanon, B.G. (2014) Traumatismes urogénitaux: Profil épidémiologique et aspects lésionnels au Centre Hospitalier Universitaire SOURO SANON de Bobo Dioulasso (Burkina Faso). Uro' Andro, 1, 83-90. https://doi.org/10.13070/rs.fr.1.949

[2] Dekou, A., Konan, P.G., Kouame, B., Vodi, C., Ouegnin, G.A., Kouame, N., et al. (2008) Les traumatismes de l'appareil génito-urinaire: Aspects épidémiologiques et lésionnels. African Journal of Urology, 14, 105-113.

https://doi.org/10.1007/s12301-008-0001-4

[3] Perrin, A., Grilo, N., Meuwly, J.Y., Jichlinski, P. and Valerio, M. (2016) Prise en charge des traumatismes uro-génitaux. Revue Médicale Suisse, 12, 2072-2076.

[4] Diabaté, I., Zé Ondo, C., Sow, I., Ba, A. and Mboup, C. (2015) Les urgences urologiques au Centre Hospitalier de LOUGA, Sénégal: Aspect épidémsiologiques et évaluation de la prise en charge. African Journal of Urology, 21, 181-186. https://doi.org/10.1016/j.afju.2015.04.004

[5] Coulibaly, M.T., Issa, A., Kassogué, A. and Ouattara, Z. (2017) Traumatisme des bourses: Aspects cliniques et thérapeutiques au service d'urologie du CHU Gabriel Touré. Mali Médical, 22, 13-16.

[6] Simonin, O., Carence, A., Delapparent, T., Karsenty, G. and Serment, G. (2006) Traumatisme de la verge et des organes génitaux. Andrologie, 16, 187-196. https://doi.org/10.1007/BF03034858

[7] Sow, Y., Fall, P.A., Diao, B., Fall, B., Ndoye, A.K. and Diagne, B.A. (2008) Les traumatismes de la verge. Andrologie, 18, 2010-2015. https://doi.org/10.1007/BF03040757

[8] Turpin, F., Hoa, D., Faix, A., Filhastre, M., Mazet, N., Rouanet de Vigne Lavit, J.P., et al. (2008) IRM de la verge: Intérêt dans le bilan post-traumatique. Journal of Radiology, 89, 303-310. https://doi.org/10.1016/S0221-0363(08)93004-3

[9] Lardellier, F., Varlet, F., François, M., Audry, G., Buisson, P., Dubois, R., et al. (2010) Traumatisme testiculaires chez l'enfant. Andrologie, 20, 194-202. https://doi.org/10.1007/s12610-010-0097-9

[10] Fakhfakh, H., Chabchoub, K., Bouhlel, A., Kétata, H., Allouch, H. and Bahoul, A. (2007) Traumatismes fermés des bourses: Stratégie de prise en charge. Andrologie, 17, 42-48. https://doi.org/10.1007/BF03041154

[11] Grima, F., Paparel, P., Devonec, M., Perrin, P., Caillot, J.L. and Ruffion, A. (2006) Prise en charge des traumatismes des corps caverneux du pénis. Progrès en Urologie, $16,12-18$.

[12] Diabaté, I., Zé Ondo, C., Ouédrago, B., Thiam, M. and Ba, A. (2017) Les amputations et autres traumatismes de la verge. African Journal of Urology, 23, 300-305. https://doi.org/10.1016/j.afju.2016.09.004 